\title{
PRE-OPERATIVE INCENTIVE SPIROMETRY; EFFECTIVENESS TO IMPROVE POST-OPERATIVE OXYGENATION IN PATIENTS UNDERGOING CABG SURGERY draamir2009@hotmail.com
}

1. Assistant Professor of Anaesthesia Children Hospital and Institute of Child Health, Multan.

2. Assistant Professor of Anaesthesia Multan Institute of Kidney Diseases, Multan.

3. Assistant Professor of Anaesthesia Nishtar Medical College, Multan.

4. Professor of Anaesthesia

Ch. Pervaiz Ellahi Institute of Cardiology, Multan

5. Associate Professor of Anaesthesia Ch. Pervaiz Ellahi Institute of Cardiology, Multan

Correspondence Address: Dr. Aamir Furqan (FCPS Anesthesia) Assistant Professor of Anaesthesia. Room No 229 Razi Hall Nishtar hospital boys hostel Multan draamir2009@hotmail.com

Article received on: 13/08/2016

Accepted for publication: 15/10/2016

Received after proof reading: $14 / 11 / 2016$

\section{Dr. Aatir Fayyaz ${ }^{1}$, Dr. Aamir Furqan ${ }^{2}$, Dr. Ali Ammar ${ }^{3}$, Prof. Rana Altaf Ahmad ${ }^{4}$, Dr. Suhail Ahmad}

ABSTRACT... Introduction: Coronary artery bypass surgery is associated with post-operative complications like, atelactasis, pneumonia, plural effusion, pulmonary edema which effect on post operative oxygenation of patient resulting in delayed recovery and prolong hospital stay. Materials and method: A total of 170 patients included in the study. Study Design: Randomized control trial. Setting: Department of Cardiac Surgery, Chaudary Pervaiz Elahi Institute of Cardiology Multan. Period: January 2016 to June 2016. Objective: To Compare postoperative oxygenation outcomes in patients undergoing CABG with and without pre-operative spirometry. Results: Oxygenation variables pre-operative mean PO2 and SD in C group was $93.27 \pm 5.04$ and in I group $97.29 \pm 2.31$. Similarly pre-operative PCO2 in C group was $41.73 \pm 3.22$ and in I group was $38.78 \pm 2.99$. Mean A-a gradient and SD in C group was $7.42 \pm 1.70$ and in I group $4.56 \pm 1.11$. At the time of shifting from theater mean PO2 in $\mathrm{C}$ group was $91.22 \pm 4.64$ and in I group was $98.20 \pm 2.00$, similarly mean PCO2 and SD in C group was $43.18 \pm 3.47$ and in I group $39.65 \pm 1.15$. Mean A-a gradient and SD in C group was $8.02 \pm 1.30$ and in I group $3.87 \pm 0.88$. After four hours mean PO2 and SD in $C$ group was $92.00 \pm 5.05$ and in I group $99.04 \pm 1.15$. Mean PCO2 after four hours in $\mathrm{C}$ group was $42.34 \pm 4.08$ and in I group $37.29 \pm$ 2.93. As concerned to A-a gradient mean and SD was $7.12 \pm 1.70$ and in I group $5.84 \pm 1.92$. Conclusion: Preoperative incentive spirometry have improved postoperative oxygenation and reduce the incidence of postoperative complications following CABG.

Key words: $\quad$ Incentive Spirometry, CABG, $\mathrm{PO}^{2}$

Article Citation: Fayyaz A, Furqan A, Ammar A, Ahmad RA, Ahmad S. Pre-operative incentive spirometry; effectiveness to improve post-operative oxygenation in patients undergoing CABG surgery. Professional Med J 2016;23(11):1368-1372. DOI: $10.17957 / T P M J / 16.3579$

\section{INTRODUCTION}

Pulmonary complications are involved in coronary artery bypass surgery, these complications adversely affect the oxygenation of patient which delayed patient's recovery, and prolonged hospital stay. ${ }^{1}$ The incidence of these abnormality is associated with altered respiratory physiology and presence of risk factors ${ }^{2}$, pleural effusion, pulmonary edema, early postoperative pneumonia are major radiological changes which can be describe post-operative pulmonary complications. $^{3}$ These changes in normal ventilation are one of the highly damaging risk factor, because it is inherent in thoracic surgery. ${ }^{4}$ Delayed recovery is most common in patients who had coronary artery bypass surgery. ${ }^{5}$ The cause of delayed recovery and prolonged hospital stay is difficult to understand because it can be caused by variety of factors, for example, pulmonary effusion, pain, general anesthesia, chest wall abnormalities, ascites, diaphragmatic malfunction or dysfunction. ${ }^{6}$ Moreover, when internal mammary artery is dissected, there is seen one sided blockage of blood supply to the intercostals muscles and phrenic nerve resulting in respiratory muscle dysfunction. ${ }^{7}$ Some techniques are also used to prevent pulmonary complications, like deep breathing exercise incentive spirometry, early mobilization and positive airway pressure..$^{8,9}$ In a recent research for clinical trial of high risk individuals undergoing CABG, Hulzebos et al discovered that intensive inspiratory muscle training (7 times a week, for at least 2 weeks before the day of surgery) has deterred these postoperative complications of $\mathrm{CABG}$ and also reduced the incidence of hospitalization after CABG. In many studies preoperative incentive spirometry is used to reduce 
the post operative pulmonary complications and to improve post operative oxygenation, but results are not sufficient to support this equipment to reduce pulmonary complications.

\section{MATERIALS AND METHODS}

It was randomized control trial conducted from January 2016 to June 2016. Ethical approval was taken from the Department of Academic Affairs of Ch. Pervaiz Elahi institution of cardiology before starting the research work. One hundred and seventy (170) patients undergoing CABG surgery were included in the study. Patients were randomly assigned into two equal groups using binary number generator system. Informed consent was taken from patients. 170 Patients will be categorized into group C (control group) and group I (Incentive spirometry group) Group I was perform preoperative incentive spirometry while group $C$ patient was not. The researcher was following all patients to observe preoperative incentive spirometry and postoperative recovery to see oxygenation. All the data was entered and analyzed using computer program SPSS version 10. Descriptive statistics was used to calculate mean and standard deviation for age, weight, height, $\mathrm{BMI}$, and oxygenation variables (pre-operative, and post operative $\mathrm{PO} 2, \mathrm{PCO} 2$ and $\mathrm{A}$-a gradient). Frequencies and percentages were calculated for gender and groups.

\section{RESULTS}

A total of 170 patients included in the study 77 (45.3\%) were male and 93 (54.7\%) were female. All patients were divided in two equal groups, C group (control group) and I group (Incentive spirometry group) 85 patients in each groups. Mean age and SD of patients in C group was 39.33 \pm 12.21 and in I group $39.44 \pm 12.06$ (Table-I). As concerned to the weight, mean weight and SD in $C$ group was $71.79 \pm 13.03$ and in I group it was $75.20 \pm 11.33$, similarly mean height and SD in $C$ group was $166.60 \pm 13.71$ and in I group $166.85 \pm 17.39$ (Table-l). Mean BMI and SD was $28.36 \pm 6.06$. As concerned to the oxygenation variables pre-operative mean PO2 and SD in C group was $93.27 \pm 5.04$ and in I group $97.29 \pm$ 2.31. Similarly pre-operative PCO2 in $\mathrm{C}$ group was $41.73 \pm 3.22$ and in I group was $38.78 \pm$ 2.99. Mean $A$-a gradient and $S D$ in $C$ group was $7.42 \pm 1.70$ and in I group $4.56 \pm 1.11$ (Table-II). At the time of shifting from theater mean $\mathrm{PO} 2$ in $\mathrm{C}$ group was $91.22 \pm 4.64$ and in I group was 98.20 \pm 2.00 , similarly mean PCO2 and SD in $\mathrm{C}$ group was $43.18 \pm 3.47$ and in I group $39.65 \pm 1.15$. Mean A-a gradient and SD in C group was 8.02 \pm 1.30 and in I group $3.87 \pm 0.88$ (Table-III). After four hours mean PO2 and SD in C group was $92.00 \pm 5.05$ and in I group $99.04 \pm 1.15$. Mean PCO2 after four hours in C group was $42.34 \pm$ 4.08 and in I group $37.29 \pm 2.93$. As concerned to A-a gradient mean and SD was $7.12 \pm 1.70$ and in I group $5.84 \pm 1.92$ (Table-IV).

\begin{tabular}{|c|c|c|c|c|c|}
\hline Groups & Mean Age \pm SD & Mean Weight \pm SD & Mean Height \pm SD & Mean BMI \pm SD \\
\hline Control group & $39.33 \pm 12.21$ & $71.79 \pm 13.03$ & $166.60 \pm 13.71$ & $26.20 \pm 5.29$ \\
\hline Incentive Spirometry group & $39.44 \pm 12.06$ & $75.20 \pm 11.33$ & $166.85 \pm 17.39$ & $28.36 \pm 6.06$ \\
\hline
\end{tabular}

\begin{tabular}{|l|c|c|c|}
\hline \multicolumn{1}{|c|}{ Groups } & $\begin{array}{c}\text { Pre-Operative PO2 } \\
\text { Mean } \pm \text { SD }\end{array}$ & $\begin{array}{c}\text { Pre-Operative PCO2 } \\
\text { Mean } \pm \text { SD }\end{array}$ & $\begin{array}{c}\text { A-a Gradient } \\
\text { Mean } \pm \text { SD }\end{array}$ \\
\hline Control Group & $93.27 \pm 5.04$ & $41.73 \pm 3.22$ & $7.42 \pm 1.70$ \\
\hline Incentive Spirometry Group & $97.29 \pm 2.31$ & $38.78 \pm 2.99$ & $4.56 \pm 1.11$ \\
\hline \multicolumn{2}{|c|}{ Table-l. Oxygenation } \\
\hline
\end{tabular}

\begin{tabular}{|l|c|c|c|}
\hline \multicolumn{1}{|c|}{ Groups } & $\begin{array}{c}\text { On Shifting PO2 } \\
\text { Mean } \pm \text { SD }\end{array}$ & $\begin{array}{c}\text { On Shifting PCO2 } \\
\text { Mean } \pm \text { SD }\end{array}$ & $\begin{array}{c}\text { A-a Gradient } \\
\text { Mean } \pm \text { SD }\end{array}$ \\
\hline Control Group & $91.22 \pm 4.64$ & $43.18 \pm 3.47$ & $8.02 \pm 1.30$ \\
\hline Incentive Spirometry Group & $98.20 \pm 2.00$ & $39.65 \pm 1.15$ & $3.87 \pm 0.88$ \\
\hline
\end{tabular}

Table-II. Oxygenation 


\begin{tabular}{|l|c|c|c|}
\hline \multicolumn{1}{|c|}{ Groups } & $\begin{array}{c}\text { After Four Hours PO2 } \\
\text { Mean } \pm \text { SD }\end{array}$ & $\begin{array}{c}\text { After Four Hours PCO2 } \\
\text { Mean } \pm \text { SD }\end{array}$ & $\begin{array}{c}\text { A-a Gradient } \\
\text { Mean } \pm \text { SD }\end{array}$ \\
\hline Control Group & $92.00 \pm 5.05$ & $42.34 \pm 4.08$ & $7.12 \pm 1.70$ \\
\hline Incentive Spirometry Group & $99.04 \pm 1.15$ & $37.29 \pm 2.93$ & $5.84 \pm 1.92$ \\
\hline
\end{tabular}

\section{DISCUSSION}

A total of 170 patients included in the study 77 (45.3\%) were male and 93 (54.7\%) were female. All patients were divided in two equal groups, C group (control group) and I group (Incentive spirometry group) 85 patients in each groups. Mean age and SD of patients in $C$ group was $39.33 \pm 12.21$ and in I group $39.44 \pm 12.06$. As concerned to the weight, mean weight and SD in $C$ group was $71.79 \pm 13.03$ and in I group it was $75.20 \pm 11.33$, similarly mean height and SD in $C$ group was $166.60 \pm 13.71$ and in I group $166.85 \pm$ 17.39. Mean BMI and SD was $28.36 \pm$ 6.06. As concerned to the oxygenation variables pre-operative mean $\mathrm{PO} 2$ and $\mathrm{SD}$ in $\mathrm{C}$ group was $93.27 \pm 5.04$ and in I group $97.29 \pm 2.31$. This result suggests that with use of spirometry technique, the preoperative oxygenation of patients was improved as $\mathrm{PO} 2$ is evidently enhanced. Similarly pre-operative PCO2 in C group was $41.73 \pm 3.22$ and in I group was 38.78 \pm 2.99. A study conducted by Ahmadreza et al in Iranian population and showed that Incentive spirometry caused a mark able improvement in $\mathrm{PO}^{2}$ and $\mathrm{PCO}^{2}$. As stated earlier spirometry technique improved PO2, similarly on the other hand when PCO2 was considered there was considerable decrease in $\mathrm{PCO} 2$ showing improved preoperative oxygenation. Mean A-a gradient and SD in $C$ group was $7.42 \pm 1.70$ and in I group $4.56 \pm$ 1.11. Mean A-a gradient result also states that spirometery has increased preoperative oxygenation. In a study by Mordian et al showed that incentive spirometry can improve $\mathrm{PaO}^{2}$ and $\mathrm{SaO}^{2}$ on post-operative day of $\mathrm{CABG} .{ }^{10}$ On the other side, there are different results reported by Afrasiabi et al. showed that the incentive spirometry does not have significant effect on improvement of post-operative oxygenation. ${ }^{11}$ Brage also reported trhat improvement in post operative oxygenation with the use of incentive spirometry is not permanent, this improvement is reversible after short time. ${ }^{12}$ At the time of shifting from theater mean PO2 in C group was $91.22 \pm$ 4.64 and in I group was $98.20 \pm 2.00$, similarly mean PCO2 and SD in C group was $43.18 \pm 3.47$ and in I group $39.65 \pm 1.15$. Hence, spirometry not only increased preoperative but when results for PO2 and PCO2 were taken after shifting the patient after operation the overall oxygenation was still improved in the I group than $\mathrm{C}$ group. Mean A-a gradient and SD in C group was 8.02 \pm 1.30 and in I group $3.87 \pm 0.88$. Another proof of how spirometry can improve oxygenation of the I group. In a study it is reported that Incentive spirometry improve oxygenation at third post operative day in our study after four hours mean PO2 and SD in C group was $92.00 \pm 5.05$ and in I group $99.04 \pm 1.15$. Mean PCO2 after four hours in $\mathrm{C}$ group was $42.34 \pm 4.08$ and in I group 37.29 \pm 2.93 . As concerned to A-a gradient mean and SD was $7.12 \pm 1.70$ and in I group $5.84 \pm 1.92$. These results taken after four hours of surgery suggest the same figures and it is well established by now that $\mathrm{PO} 2$ is better and PCO2 is decreased in I group as compared to $\mathrm{C}$ group.

However there was no record of pulmonary infection in any group of patients and no difference in their hospital or ICU stay. ${ }^{13,14}$

Although breathing exercise is performed by almost every CABG patient, but different studies all over the world has shown that in some countries this treatment is not much efficient. ${ }^{15,16,17,18}$ The physical treatment costs and has its own adverse effects. ${ }^{19}$

During our study, preoperative, at the time of shifting and and 4th day after CABG surgery pulmonary function measurements were taken. Like previous investigations, a marked reduction in lung volume was evident on fourth day after surgery. ${ }^{20,21}$ Moreover the spirometric variables were also improved in patients who performed breathing exercise on the fourth day as 
compared to the control group, however effect on oxygenation was more obvious. Different studies which involved control group patients who did not receive any breathing physiotherapy is limited these days. Recruited lung tissue in the form of stunt is grafted on zone where oxygenation is still poor because of less perforation as compared to ventilation. ${ }^{22,23}$

Mixed venous oxygen tension or cardiac output and efficiency of hypoxic pulmonary vasoconstriction are non-pulmonary factors which contribute to affect the arterial oxygenation. ${ }^{24}$

\section{CONCLUSION}

Preoperative incentive spirometry have improved postoperative oxygenation and reduce the incidence of postoperative complications following CABG.

Copyright $(15$ Oct, 2016.

\section{REFERENCES}

1. O'Donohue WJ Jr. Postoperative pulmonary complications. When are preventive and therapeutic measures necessary? Postgrad Med.1992; 91(3):16770.

2. Kips JC. Preoperative pulmonary evaluation. Acta Clin Belg.1997; 52(5):301-05.

3. Doyle RL. Assessing and modifying the risk of postoperative pulmonary complications. Chest.1999; 115(5 Suppl):77-81.

4. Weissman C. Pulmonary complications after cardiac surgery. Semin Cardiothorac Vasc Anesth.2004; 8(3):185-211.

5. Tenling A, Hachenberg $\mathrm{T}$, Tyden $\mathrm{H}$, Wegenius $\mathrm{G}$, Hedenstierna G: Atelectasis and gas exchange after cardiac surgery. Anesthesiology.1998; 89(2):371-78.

6. Massard G, Wihlm JM: Postoperative atelectasis. Chest Surg Clin N Am. 1998; 8(3):503-28.

7. Abd AG, Braun NM, Baskin Ml, O'Sullivan MM, Alkaitis $D A$. Diaphragmatic dysfunction after open heart surgery: treatment with a rocking bed. Ann Intern Med. 1989; 111(11):881-6.

8. Wynne R, Botti M. Postoperative pulmonary dysfunction in adults after cardiac surgery with cardiopulmonary bypass: Clinical significance and implications for practice. Am J Crit Care 2004; 13:384 93.
9. Zarbock A, Mueller E, Netzer S, Gabriel A, Feindt P, Kindgen Milles D. Prophylactic nasal continuous positive airway pressure following cardiac surgery protects from postoperative pulmonary complications a prospective, randomized, controlled trial in $\mathbf{5 0 0}$ patients. Chest 2009; 135:1252 9.

10. Moradyan S, Farahani M, Mohammadi N, Jamshidi $R$. The effect of planned breathing exercises on oxygenation in patients after coronary artery bypass surgery. Cardiovasc Nurs J Spring 2012; 1:8-14.

11. Afrasiabi A, Hasanzadeh S, Negargar S, Ghafari MR, Ansarin $K$. The effect of incentive spirometry on pulmonary volumes and arterial blood gases after coronary artery bypass surgery. J Kermanshah Univ Med Sci 2007; 10:1.

12. Brage I, Fernandez S, Stein A, Gonzalez U, Diaz S, Garcia A. Respiratory physiotherapy and incidence of pulmonary complication in off pump coronary artery bypass graft surgery: An observational follow up study. BMC Pulm Med 2009; 9:466 9.

13. Johnson, NT, Pierson, DJ The spectrum of pulmonary atelectasis: pathophysiology, diagnosis, and therapy. Respir Care1986; 31, 1107-1120.

14. Woodring, $\mathrm{JH}$, Reed, JC Types and mechanisms of pulmonary atelectasis. J Thorac Imaging1996; 11,92108.

15. Crowe, JM, Bradley, CA. The effectiveness of incentive spirometry with physical therapy for highrisk patients after coronary artery bypass surgery. Phys Ther.1997; 77:260-68.

16. Stiller, K, Montarello, J, Wallace, M. Efficacy of breathing and coughing exercises in the prevention of pulmonary complications after coronary artery surgery. Chest.1994; 105:741-47.

17. Brasher, PA, McClelland, KH, Denehy L. Does removal of deep breathing exercises from a physiotherapy program including pre-operative education and early mobilization after cardiac surgery alter patient outcomes? Aust J Physiother.2003; 49:165-73.

18. Overend, TJ, Anderson, CM, Lucy, SD. The effect of incentive spirometry on postoperative pulmonary complications: a systematic review. Chest.2001; 120:971-78.

19. Pasquina, P, Tramer, MR, Walder, B Prophylactic respiratory physiotherapy after cardiac surgery: systematic review. BMJ. 2003; 327:79.

20. Westerdahl, E, Lindmark, B, Almgren, SO. Chest physiotherapy after coronary artery bypass graft surgery: a comparison of three different deep 
breathing techniques. J Rehabil Med.2001; 33, 79-84.

21. Jenkins, SC, Soutar, SA, Forsyth, A. Lung function after coronary artery surgery using the internal mammary artery and the saphenous vein. Thorax.1989; 44:20911.

22. Marshall, BE, Hanson, CW, Frasch, F. Role of hypoxic pulmonary vasoconstriction in pulmonary gas exchange and blood flow distribution: 2 . Pathophysiology. Intensive Care Med.1994; 20:379-89.
23. Rothen, HU, Sporre, B, Engberg, G. Influence of gas composition on recurrence of atelectasis after a reexpansion maneuver during general anesthesia. Anesthesiology.1995; 82:832-42.

24. Anjou-Lindskog, E, Broman, L, Broman, M. Effects of oxygen on central haemodynamics and $V A / Q$ distribution after coronary bypass surgery. Acta Anaesthesiol Scand.1983; 27:378-84.

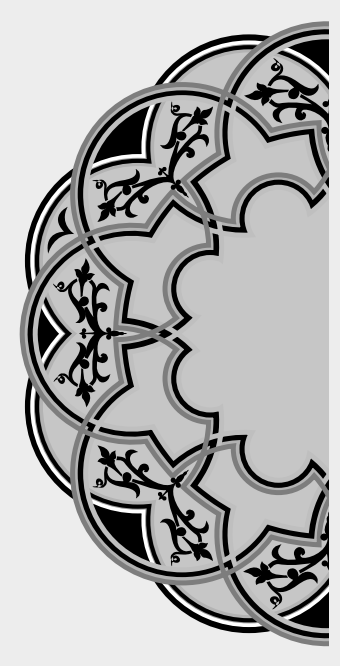

\section{"Two things define you: \\ Your patience when you have nothing, and your attitude when you have everything."}

\section{Unknown}

\section{AUTHORSHIP AND CONTRIBUTION DECLARATION}

\begin{tabular}{|c|l|}
\hline Sr. \# & \multicolumn{1}{|c|}{ Author-s Full Name } \\
\hline 1 & Dr. Aatir Fayyaz \\
2 & Dr. Aamir Furqan \\
3 & Dr. Ali Ammar \\
4 & Prof. Rana Altaf Ahmad \\
5 & Dr. Suhail Ahmad \\
\hline
\end{tabular}

Contribution to the paper

Concieve idea, manuscript writing

Manuscript writing, data collection and data analysis statistical analysis of data

Proof reading, given final approval of study Data collection and data analysis 